\title{
Effects of dietary fermented spent coffee ground on nutrient digestibility and nitrogen utilization in sheep
}

\author{
Yongjun Choi ${ }^{1}$, Jong-su $\operatorname{Rim}^{1}$, Youngjun $\mathrm{Na}^{1}$, and Sang Rak Lee ${ }^{1, *}$
}

* Corresponding Authors: Sang Rak Lee Tel: +82-2-450-3696, Fax: +82-2-455-1044

E-mail: leesr@konkuk.ac.kr

1 Department of Animal Science and Technology, Konkuk University, Seoul 05029, Korea

ORCID

Yongjun Choi

https://orcid.org/0000-0002-5759-4108 Youngjun $\mathrm{Na}$

https://orcid.org/0000-0002-4643-0191

Sang Rak Lee

https://orcid.org/0000-0002-8905-0770

Submitted Sept 6, 2017; Revised Oct 11, 2017; Accepted Oct 23, 2017
Objective: The objective of the study was to determine the effect of fermented spent coffee ground (FSCG) on nutrient digestibility and nitrogen utilization in sheep.

Methods: Fermentation of spent coffee ground (SCG) was conducted using Lactobacillus plantrum. Fermentation was performed at moisture content of $70 \%$ and temperature of $39^{\circ} \mathrm{C}$ with anaerobic air tension for $48 \mathrm{~h}$. Four adult rams (initial body weight $=56.8 \pm 0.4 \mathrm{~kg}$ ) were housed in a respiration-metabolism chamber and the treatments were: i) control (Basal diet; 0\% SCG or FSCG), ii) 10\% level of SCG, iii) 10\% level of FSCG, and iv) 20\% level of FSCG in $4 \times 4$ Latin square design. Each dietary experiment period lasted for 18-d with a 14 -d of adaptation period and a $4-\mathrm{d}$ of sample collection period.

Results: In SCG fermentation experimental result, acid detergent insoluble nitrogen (ADIN) concentration of FSCG ( $64.5 \%$ of total N) was lower than that of non-fermented SCG $(78.8 \%$ of total N). Digestibility of dry matter and organic matter was similar among treatment groups. Although crude protein $(\mathrm{CP})$ digestibility of the control was greater than FSCG groups ( $\mathrm{p}<$ 0.05 ), the $10 \%$ FSCG group showed greater CP digestibility and nitrogen retention than nonfermented $10 \%$ SCG group $(\mathrm{p}<0.05)$. Body weight gain and average daily gain were linearly decreased with increasing FSCG feeding level $(\mathrm{p}<0.05)$. When the feeding level of FSCG was increased, water intake was linearly increased $(\mathrm{p}<0.05)$. With an increasing FSCG level, dry matter intake did not differ among groups, although the gain to feed ratio tended to decrease with increasing level of FSCG $(\mathrm{p}<0.10)$.

Conclusion: Microbial fermentation of SCG can improve protein digestibility, thereby increasing $\mathrm{CP}$ digestibility and nitrogen utilization in sheep. Fermentation using microorganisms in feed ingredients with low digestibility could have a positive effect on improving the quality of raw feed.

Keywords: Feed Intake; Fermented Spent Coffee Ground; Nutrient Digestibility; Nitrogen Utilization; Sheep

\section{INTRODUCTION}

Coffee bean is the second major trade product (next to oil) in the world [1]. In general, coffee beans are roasted, ground, and extracted to produce coffee beverages; their remains are disposed. With increasing international coffee trade, the generation of spent coffee ground (SCG) is also increased. When SCG is not disposed properly, it might pose risk to the environment. For this reason, some studies have attempted to utilize SCG for biodiesel production or as source of sugar, compost, and sorbent for metal ions removal [2]. However, little work has been done to evaluate SCG as animal feed.

Since coffee contains antioxidants such as caffeine, polyphenols, and melanoidin [3], these compounds might have beneficial effect on animal. Previous studies have reported that coffee ground contains $13.8 \%$ to $14.5 \%$ of crude protein (CP), $13.6 \%$ to $18.4 \%$ of ether extract (EE), 
$64.6 \%$ to $68.8 \%$ of neutral detergent fiber (NDF), and $45.1 \%$ to $54.8 \%$ of acid detergent fiber (ADF) [4,5], these results seems to be more useful in ruminants than monogastric animal as feed ingredient. However, there is some potential limitation to use SCG as feed ingredient for ruminant due to its low palatability and nitrogen digestibility $(-0.92 \%$ to $-0.53 \%)$ in sheep [6]. For this reason, improving the palatability and digestibility of SCG is needed when it might be a useful feed ingredient for ruminants.

Feed intake and palatability are affected by the characteristics of feed ingredients such as shape, smell, taste, texture, particle size, and temperature [7]. Some trials have been conducted to improve the palatability of feeds using microbial fermentation and organic acid supplement. For example, the addition of propionic acid [8] and lactic acid $[9,10]$ to animal feeds can improve their palatability. Previous studies reported micorbes could help decoloriztion of waterwaste malanoidin [11]. Furthermore, lactobacillus plantarum isolated from pickle was shown decoloriztion of molasses wastewater including melinodin [12].

Therefore, the objective of this study was to determine the effect of fermentation using bacteria on nutrient digestibility and nitrogen utilization in sheep.

\section{MATERIALS AND METHODS}

The experiment was performed in compliance with the guidelines of the Institutional Animal Care and Use Committee of Konkuk University (KU 13092).

\section{Spent coffee ground and fermentation}

Spent coffee ground samples were collected at instant coffee beverage factory of Dong-Suh Food Industry (Incheon, Korea). Lactobacillus plantarum (ATCC 14917) was used for SCG fermentation. Lactobacillus plantarum with $1 \times 10^{7} \mathrm{cfu} / \mathrm{mL}$ was cultured in a medium $(500 \mathrm{~mL})$ containing $24.5 \mathrm{~g}$ of Lactobacilli MRS broth (Difco Laboratories, Madrid, Spain) and then incubated at $37^{\circ} \mathrm{C}$ for $24 \mathrm{~h}$. Microorganism for fermentation was inoculated using culture medium as $1 \mathrm{~mL}$ per SCG $\mathrm{g}$ dry matter (DM). Fermentation condition was determined in compliance with the guidelines of the ATCC optimum growth condition [13]. Fermentation was performed at moisture of $70 \%$ and temperature of $37^{\circ} \mathrm{C}$ with anaerobic air tension for $48 \mathrm{~h}$. SCG and inoculum were mixed and sealed using 1,242 $\mathrm{mL}$ capacity (42 oz) polyethylene bags (Whil-pak detectable bag, Sigma-aldrich, St. Louis, MO, USA). All experiments were performed with three replicates. About $50 \mathrm{~g} / \mathrm{kg}$ of molasses were added as energy source for smooth fermentation.

\section{Animals and experiment design}

A total of four rams (Initial body weight: $56.8 \pm 0.4 \mathrm{~kg}$ ) were used in a $4 \times 4$ Latin square design. Each animal was individ- ually housed in a metabolism chamber $(1.47 \times 0.53 \times 1.37 \mathrm{~m})$ system at controlled temperature $\left(20.4^{\circ} \mathrm{C} \pm 2.0^{\circ} \mathrm{C}\right)$ and humidity $\left(27.4^{\circ} \mathrm{C} \pm 2.0^{\circ} \mathrm{C}\right)[14]$. Each dietary experiment period lasted for 18-d with a 14-d adaptation period and 4-d sample collection period. Fecal and urine were collected at $1000 \mathrm{~h}$ during sampling period using method of Li et al [14]. The treatments were: i) control (Basal diet; 0\% SCG or fermented spent coffee ground [FSCG]), ii) 10\% level of SCG, iii) 10\% level of FSCG, and iv) 20\% level of FSCG (DM basis) (Table 1). These animals were fed ad libitum in the form of total mixed ration at 1000 $\mathrm{h}$ and $1800 \mathrm{~h}$ in the form of total mixed ration and the experimental diets were fed $105 \%$ of the previous day of feed intake and refusals were weighted daily before the first feeding to measure dry matter intake (DMI). Experiment diet was formulated according to NRC guideline [15]. In experimental diets, alfalfa (CP: 13\% DM) and timothy (CP: $8 \% \mathrm{DM})$ was replaced by SCG and FSCG. Mineral blocks ( $\mathrm{Na}, 388 \mathrm{~g} / \mathrm{kg}$; $\mathrm{Mg}, 330 \mathrm{mg} / \mathrm{kg}$; Co, $0.25 \mathrm{mg} / \mathrm{kg}$; Fe, 90 mg/kg; Mn, 25 mg/kg; Zn, 14 mg/kg; I 5.5 mg/kg, Farmvas block, Deltavit, France) was fed ad libitum. The water was fed 4 liters per day with experiment diet and the residue was measured to determine water intake at $1000 \mathrm{~h}$ daily. Body weight (BW) was measured at initiation of experiment and every sampling period before feeding at $1000 \mathrm{~h}$. The body weight gain (BWG) and average daily gaein (ADG) was calculated using the mean value of intial BW and final BW of each period.

Table 1. Ingredient proportions and chemical compositions of experimental diets

\begin{tabular}{|c|c|c|c|c|}
\hline \multirow{3}{*}{ Item } & \multicolumn{4}{|c|}{ Treatment (\% DM) } \\
\hline & \multirow{2}{*}{$\begin{array}{c}\text { Control } \\
0\end{array}$} & \multirow{2}{*}{$\begin{array}{c}\text { SCG } \\
10\end{array}$} & \multicolumn{2}{|c|}{ FSCG } \\
\hline & & & 10 & 20 \\
\hline \multicolumn{5}{|l|}{ Ingredient (\% DM basis) } \\
\hline Spent instant coffee ground & 0.0 & 10.0 & 10.0 & 20.0 \\
\hline Timothy hay (CP: 8.0\% DM) & 36.0 & 28.8 & 28.8 & 23.9 \\
\hline Alfalfa hay (CP: 13.0\% DM) & 27.6 & 24.8 & 24.8 & 19.9 \\
\hline Corn & 28.0 & 28.0 & 28.0 & 28.0 \\
\hline Soybean meal (CP: 49.0\% DM) & 8.3 & 8.3 & 8.3 & 8.3 \\
\hline \multicolumn{5}{|l|}{ Chemical composition") } \\
\hline DM (\%) & 63.0 & 63.2 & 63.3 & 63.6 \\
\hline OM (\% DM) & 94.1 & 94.8 & 94.8 & 95.6 \\
\hline $\mathrm{CP}(\% \mathrm{DM})$ & 13.1 & 13.3 & 13.3 & 13.5 \\
\hline $\mathrm{EE}(\% \mathrm{DM})$ & 2.6 & 3.8 & 3.8 & 5.0 \\
\hline NDF (\% DM) & 43.6 & 45.1 & 45.1 & 47.0 \\
\hline ADF (\% DM) & 28.6 & 31.8 & 31.8 & 35.0 \\
\hline $\mathrm{NFC}(\% \mathrm{DM})^{2)}$ & 34.8 & 32.6 & 32.6 & 30.1 \\
\hline $\mathrm{Ca}(\% \mathrm{DM})$ & 0.5 & 0.5 & 0.5 & 0.4 \\
\hline $\mathrm{P}(\% \mathrm{DM})$ & 0.3 & 0.3 & 0.3 & 0.2 \\
\hline GE (MJ/kg DM) & 21.3 & 21.0 & 21.0 & 20.9 \\
\hline
\end{tabular}

DM, dry matter; SCG, spent coffee ground; FSCG, fermented spent coffee ground; $C P$, crude protein; $\mathrm{OM}$, organic matter; $\mathrm{EE}$, ether extract; aNDF, neutral detergent fiber; ADF, acid detergent fiber; NFC, non-fiber carbohydrates; GE, gross energy.

1) $\mathrm{Ca}$ and $\mathrm{P}$ was measured after experimental diet formulation.

${ }^{2)} \mathrm{NFC}=\mathrm{OM}-\mathrm{aNDF}-\mathrm{CP}-\mathrm{EE}-\mathrm{ash}$. 


\section{Chemical analysis}

Feed ingredients and fecal samples were dried in an oven (HB503-LF, Hanbaek Scientific Technology, Korea) at $60^{\circ} \mathrm{C}$ for 48 $\mathrm{h}$. They were ground and passed 1-mm screen with a micro hammer mill (Nr9737840, Culatti AG, Steinerberg, Switzerland). The $\mathrm{DM}$, organic matter (OM), $\mathrm{CP}, \mathrm{EE}$, nitrogen contents and $\mathrm{pH}$ were then analyzed according to AOAC method [16]. The NDF and ADF were analyzed using ANKOM Fiber Analyzer (A200, ANKOM Inc., Macedon, NY, USA) according to the method of Soest et al [17]. Acid detergent insoluble nitrogen (ADIN) was determined using $\mathrm{ADF}$ residue according to the method of Licitra et al [18]. Gross energy was analyzed using automatic bomb calorimeter (Parr 1261 bomb calorimeter, Parr Instruments Co., Moline, Illinois, USA). Pretreatment of FSCG and experimental feed for volatile fatty acid (VFA) were determined using the method of cold water extracts at $4^{\circ} \mathrm{C}$ for $24 \mathrm{~h}$ [19]. Ammonia nitrogen was conducted according to the method of Chaney and Marbach [20]. The VFA of SCG and FSCG was determined by gas chromatography (HP 6890, Agilent Technologies, Santa Clara, CA, USA) equipped with Omega Wax Fused Silica Capillary Column (Length, $30 \mathrm{~m}$ $0.3 \times 2 \mathrm{~mm}$; df, $0.25 \mu \mathrm{m}$, Sigma-Aldrich Co, USA) using flame ionization detector and carrier gas was He gas [21].

\section{Statistical analysis}

Data were analyzed using PROC MIXED of SAS package program (SAS Inst. Inc., Cary, NC, USA) with a $4 \times 4$ Latin square design [22]. Model was:

$$
\mathrm{Y}_{\mathrm{ij}}(\mathrm{t})=\mu+\mathrm{R}_{\mathrm{i}}+\mathrm{C}_{\mathrm{j}}+\mathrm{T}(\mathrm{t})+\mathrm{E}_{\mathrm{ij}}(\mathrm{t})
$$

Where $\mu$ was an average value, $R_{i}$ was an animal, $C_{j}$ was a period, $T_{i}$ was treatment value, and $E_{i j}$ was the error value. Fixed effect was treatment effect, and a random effect was animal and period in the procedure. Difference among each treatment was determined least significant difference test using PDIFF option. Polynomial orthogonal contrasts were used to determine the effect of increasing FSCG using CONTRAST option. Difference in fermentation effect (10\% SCG vs 10\% FSCG) was determined using PROC TTEST. Statistical difference and tendency were accepted at $p$-value of less than 0.05 and 0.10 , respectively. All means are presented as least square means.

\section{RESULTS}

\section{Fermentation quality}

Changes in chemical compositions and fermentation indicators are summarized in Table 2. The OM content was decreased $(\mathrm{p}<0.001)$ after $48 \mathrm{~h}$ of fermentation. However, CP was increased $(p=0.003)$ after the fermentation. Acid detergent insoluble $\mathrm{N}$ concentration was increased $(\mathrm{p}=0.005)$ after 48
Table 2. Chemical compositions and fermentation profiles of spent coffee ground after $48 \mathrm{~h}$ of microbial fermentation

\begin{tabular}{lcccc}
\hline \multirow{2}{*}{ Item } & \multicolumn{2}{c}{ Fermentation time (h) } & & \\
\cline { 2 - 3 } & $\mathbf{0}$ & $\mathbf{4 8}$ & & p-value \\
\hline Chemical composition & & & & \\
DM (\%) & 47.0 & 28.7 & 0.00 & $<0.001$ \\
OM (\% DM) & 99.6 & 97.8 & 0.00 & $<0.001$ \\
CP (\% DM) & 12.0 & 14.1 & 0.10 & 0.003 \\
EE (\% DM) & 10.8 & 10.9 & 0.09 & 0.715 \\
NDF (\% DM) & 79.6 & 80.2 & 0.01 & 0.414 \\
ADF (\% DM) & 74.0 & 74.6 & 0.01 & 0.375 \\
ADIN (\% of total N) & 78.8 & 64.5 & 1.06 & 0.005 \\
Fermentation profile & & & & \\
pH & 5.57 & 3.63 & 0.01 & $<0.001$ \\
Acetic acid (\% DM) & 5.05 & ND & 0.02 & $<0.001$ \\
Propionic acid (\% DM) & ND & ND & - & - \\
Butyric acid (\% DM) & ND & ND & - & - \\
Lactic acid (\% DM) & ND & 5.83 & 0.15 & $<0.001$ \\
Ammonia nitrogen (\% DM) & 0.86 & 0.89 & 0.02 & 0.325 \\
\hline
\end{tabular}

SEM, standard error of the mean; $\mathrm{DM}$, dry matter; $\mathrm{OM}$, organic matter; $\mathrm{CP}$, crude protein; EE, ether extract; aNDF, neutral detergent fiber; $A D F$, acid detergent fiber; ADIN, acid detergent insoluble nitrogen; ND, not detected.

$\mathrm{h}$ of fermentation. The $\mathrm{pH}$ of SCG was decreased $(\mathrm{p}<0.001)$ after the fermentation. Acetic acid concentration of SCG at $0 \mathrm{~h}$ was $50.5 \mathrm{~g} / \mathrm{kg}$ of DM. It was undetectable after $48 \mathrm{~h}$ of fermentation. Lactic acid content was increased $(\mathrm{p}<0.001)$ after the $48 \mathrm{~h}$ of fermentation.

Body weight gain, dry matter intake, water intake, and gain to feed ratio

Body weight gain $(p=0.007)$ and average daily gain $(p=0.016)$ were linearly decreased with increasing feeding level of FSCG (Table 3). Water intake and urine excretion in the 20\% FSCG feeding group were greater $(p<0.05)$ than those in the basal diet feeding group. As the feeding level of FSCG was increased, water intake and urine excretion were linearly $(\mathrm{p}<0.05)$ increased. However, DMI was not affected by dietary treatments. The gain to feed ratio $(\mathrm{G}: \mathrm{F})$ tended to decrease $(\mathrm{p}=0.089)$ with increasing feeding level of FSCG.

\section{Nutrient digestibility and nitrogen utilization}

Nutrient digestibility of DM and OM content was similar among treatment groups (Table 4 ). The $\mathrm{CP}$ digestibility of the $20 \%$ FSCG feeding group was lower $(\mathrm{p}=0.011)$ than that of the control. The 10\% FSCG group showed greater $(\mathrm{p}=0.046)$ $\mathrm{CP}$ digestibility than the non-fermented $10 \%$ SCG group. Nitrogen retention in rams fed control was greater $(p=0.007)$ than SCG and FSCG feeding group. As the feeding level of FSCG was increased, nitrogen retention was linearly $(\mathrm{p}=0.025)$ decreased. Nitrogen retention in rams fed FSCG tended to be greater $(\mathrm{p}=0.090)$ than that in the SCG feeding group. 
Table 3. Body weight gain, average daily gain, water intake, dry matter intake, and gain to feed ratio of rams fed spent coffee ground or fermented spent coffee ground

\begin{tabular}{|c|c|c|c|c|c|c|c|c|c|}
\hline \multirow{3}{*}{ Item } & \multicolumn{4}{|c|}{ Treatment (\% DM) } & \multirow{3}{*}{ SEM } & \multirow{2}{*}{\multicolumn{4}{|c|}{ p-value ${ }^{1)}$}} \\
\hline & \multirow{2}{*}{$\begin{array}{c}\text { Control } \\
0\end{array}$} & \multirow{2}{*}{$\begin{array}{c}\text { SCG } \\
10\end{array}$} & \multicolumn{2}{|c|}{ FSCG } & & & & & \\
\hline & & & 10 & 20 & & Treatment & Fermentation & Linear & Quadratic \\
\hline Initial BW (kg) & 56.3 & 57.0 & 56.6 & 57.2 & 3.20 & 0.921 & 0.798 & 0.586 & 0.897 \\
\hline Finial BW (kg) & 62.0 & 60.1 & 61.3 & 60.0 & 2.68 & 0.203 & 0.242 & 0.203 & 0.803 \\
\hline BWG $(\mathrm{kg} / \mathrm{d})$ & 5.70 & 3.11 & 4.72 & 2.80 & 0.89 & 0.064 & 0.151 & 0.007 & 0.958 \\
\hline $\operatorname{ADG}(\mathrm{kg} / \mathrm{d})$ & 0.41 & 0.22 & 0.34 & 0.20 & 0.06 & 0.058 & 0.142 & 0.016 & 0.529 \\
\hline Water intake $(\mathrm{L} / \mathrm{d})$ & $8.8^{b}$ & $10.3^{\mathrm{ab}}$ & $10.1^{\mathrm{ab}}$ & $12.6^{\mathrm{a}}$ & 1.69 & 0.024 & 0.833 & 0.017 & 0.425 \\
\hline Urine excretion (L/d) & $4.3^{b}$ & $6.1^{a b}$ & $5.9^{\mathrm{ab}}$ & $9.3^{\mathrm{a}}$ & 1.50 & 0.032 & 0.864 & 0.025 & 0.480 \\
\hline $\mathrm{DMI}(\mathrm{kg} / \mathrm{d})$ & 2.06 & 2.02 & 2.00 & 1.89 & 0.18 & 0.369 & 0.820 & 0.214 & 0.871 \\
\hline Gain to feed ratio & 0.24 & 0.12 & 0.19 & 0.13 & 0.05 & 0.190 & 0.334 & 0.089 & 0.961 \\
\hline
\end{tabular}

DM, dry matter; SCG, spent coffee ground; FSCG, fermented spent coffee ground; SEM, standard error of the mean; BW, body weight; BWG, body weight gain; ADG, average daily gain; $\mathrm{DMI}$, dry matter intake.

1) Treatment, multiple comparison test among all treatments; Fermentation, SCG 10\% vs FSCG 10\%; linear, linear contrast effect among 0\%, 10\%, and 20\% of FSCG; quadratic, quadratic contrast effect among $0 \%, 10 \%$, and $20 \%$ of FSCG.

${ }^{a b}$ Means within each row with different superscripts were significantly different from each other $(p<0.05)$.

\section{DISCUSSION}

After fermentation, decreasing OM contents in SCG were considered because carbohydrate sources in SCG were used as substrates for microbial fermentation. Similarly, CP content in FSCG was higher than SCG, as it is considered that the ratio of CP in FSCG is increased consuming OM by microorganism. When coffee beans are roasted before beverage extraction, non-enzymatic chemical reaction between amino acids and reducing sugar (Maillard reaction) will occur, thereby decreasing the nutrient digestibility [23]. For this reason, only limited amounts of SCG in general could be used as ruminant feed ingredient due to its low protein digestibility [24] and palat- ability [25]. The ADIN has been used to identify indigestible protein in animal gastro-intestinal tract [17]. In the current study, ADIN concentration was decreased through microbial fermentation. Therefore, it could improve the protein quality of SCG. This considered that might be due to microbial breaking of indigestible protein and increasing microbial protein. Since fermented SCG contained more lactic acid, the endproduct of microbial fermentation [26], than non-fermented SCG, FSCG showed lower pH than non-fermented SCG. The low $\mathrm{pH}$ and high lactic acid concentration of FSCG might not only improve its preservation period, but also its palatability [9]. Therefore, microbial fermentation technique could help increase digestible protein and decreasing $\mathrm{pH}$ was could have

Table 4. Nutrient digestibility and nitrogen utilization of rams fed spent coffee ground or fermented spent coffee ground

\begin{tabular}{|c|c|c|c|c|c|c|c|c|c|}
\hline \multirow{3}{*}{ Item } & \multicolumn{4}{|c|}{ Treatment (\% DM) } & \multirow{3}{*}{ SEM } & \multirow{2}{*}{\multicolumn{4}{|c|}{ p-value ${ }^{1)}$}} \\
\hline & \multirow{2}{*}{$\begin{array}{c}\text { Control } \\
0\end{array}$} & \multirow{2}{*}{$\begin{array}{c}\text { SCG } \\
10\end{array}$} & \multicolumn{2}{|c|}{ FSCG } & & & & & \\
\hline & & & 10 & 20 & & Treatment & Fermentation & Linear & Quadratic \\
\hline DM & 60.9 & 57.7 & 59.8 & 60.0 & 4.54 & 0.538 & 0.371 & 0.631 & 0.675 \\
\hline $\mathrm{OM}$ & 63.3 & 59.6 & 61.9 & 61.4 & 4.06 & 0.408 & 0.303 & 0.529 & 0.848 \\
\hline ADF & 54.5 & 49.5 & 53.0 & 48.5 & 3.71 & 0.333 & 0.361 & 0.008 & 0.340 \\
\hline \multicolumn{10}{|l|}{ Nitrogen utilization } \\
\hline Intake (g/d) & 44.5 & 43.0 & 43.1 & 39.6 & 4.18 & 0.395 & 0.748 & 0.739 & 0.844 \\
\hline Fecal (g/d) & 17.0 & 19.0 & 16.8 & 17.6 & 1.88 & 0.363 & 0.187 & 0.484 & 0.075 \\
\hline Urinary (g/d) & $14.5^{b}$ & $16.4^{\mathrm{ab}}$ & $17.9^{\mathrm{a}}$ & $16.8^{\mathrm{ab}}$ & 1.74 & 0.046 & 0.429 & 0.103 & 0.900 \\
\hline
\end{tabular}

DM, dry matter; SCG, spent coffee ground; FSCG, fermented spent coffee ground; SEM, standard error of the mean; OM, organic matter; CP, crude protein; aNDF, neutral detergent fiber; $A D F$, acid detergent fiber.

1) Treatment, multiple comparison test among all treatments; Fermentation, SCG 10\% vs FSCG 10\%; linear, linear contrast effect among 0\%, 10\%, and 20\% of FSCG; quadratic, quadratic contrast effect among $0 \%, 10 \%$, and $20 \%$ of FSCG.

${ }^{2)}$ Retained $=($ intake $\mathrm{N}-$ fecal $\mathrm{N}$ - urinary $\mathrm{N})$ /intake $\mathrm{N} \times 100$.

${ }^{a b}$ Means within each row with different superscripts were significantly different from each other $(p<0.05)$. 
positive effect on feed ingredient store period, thereby enhancing the feed quality of SCG.

Although there was no difference among treatments on DMI, BWG, and ADG were linearly decreased with increasing feeding levels of FSCG. In this study, experimental feed of each treatment was fomulated gross energy basis. These results were considered that because the digestible energy of SCG was lower than alfalfa and timothy forages. Xu et al [25] have reported that DMI values of wethers decreased when the feeding levels of wet coffee ground increased. However, the DMI of $10 \%$ wet coffee ground (DM basis) feeding group was similar to that of the control group [25]. In addition, some studies reported that the anaerobic fermentation using lactic acid bacteria can increase the palatability and DMI of animals [27]. However, In the present study, the effect of FSCG supplementation on the DMI of the rams was did not differ among the treatments. Increasing water intake and urine excretion in SCG or FSCG feeding group might be due to the fact that caffeine contents in SCG altered body fluid and water-electrolyte balance [28].

Previous study has reported that increasing wet coffee ground in rations can linearly decrease the $\mathrm{DM}, \mathrm{OM}, \mathrm{CP}$, and $\mathrm{ADF}$ digestibility of wethers [25]. However, DM and OM digestibility of rams were similar among treatment groups in the current study. As described above on fermentation quality determination, decreased ADIN by fermentation was showed that indigestible protein content of SCG was decreased. This provides evidence that $10 \%$ FSCG resulted in greater CP digestibility than $10 \%$ SCG, which is in good agreement with results of fermentation quality determination. In addition, nitrogen utilization of rams tends to improve in the 10\% FSCG feeding group compared to that in the 10\% SCG feeding group $(p=0.09)$. CP digestibility was linearly decreased with increasing level of FSCG. For diet formulation of the current study, $\mathrm{CP}$ content of the control diet was adjusted using forages (alfalfa and timothy hay) instead of SCG. It appeared that although CP content of each experimental diet were similar, CP content of FSCG containing diet might constitute more indigestible CP content originating from FSCG or SCG than the control diet. Although, a consequence, SCG is difficult to be digested in animals [29] due to treated at high temperature and high pressure in the process of making coffee into beverage [23], the result of this experiment was seems to be a synergy of a combination of a nitrogen-free sugar (molasses) and a nitrogen source which is difficult to utilize (SCG). Furthermore, it was considered that additional study was necessary to perform about a combination of a nitrogen-free sugar and low availability nitrogen source.

In current study, as a result, the fermentation using microorganism was showed that possibility of $\mathrm{CP}$ digestibility improvement in ruminant.

\section{CONCLUSION}

This study determined the effect of SCG and FSCG on nutrient digestibility and nitrogen utilization in sheep. Lactic acid bacteria fermentation technique can improve its nitrogen quality. Increasing the feeding level of FSCG decreased the digestibility of $\mathrm{CP}$ and $\mathrm{ADF}$ in rams. However, $\mathrm{CP}$ digestibility and nitrogen retention in the 10\% FSCG feeding group were greater than those in the $10 \%$ SCG feeding group. Therefore, fermentation of SCG using microorganism can improve its protein availability, thereby increasing the CP digestibility and nitrogen utilization in sheep.

\section{CONFLICT OF INTEREST}

We certify that there is no conflict of interest with any financial organization regarding the material discussed in the manuscript.

\section{ACKNOWLEDGMENTS}

This work was supported by Korea Institute of Planning and Evaluation for Technology in Food, Agriculture, Forestry and Fisheries (IPET) through Advanced Production Technology Development Program, funded by Ministry of Agriculture, Food and Rural Affairs (MAFRA) (116056-03).

\section{REFERENCES}

1. Machado EMS, Rodriguez-Jasso RM, Teixeira JA, Mussatto I. Growth of fungal strains on coffee industry residues with removal of polyphenolic compounds. Biochem Eng J 2012;60: 87-90.

2. Campos-Vega R, Loarca-Piña G, Vergara-Castañeda HA, Oomah BD. Spent coffee grounds: A review on current research and future prospects. Trends Food Sci Technol 2015;45:24-36.

3. Vignoli JA, Bassoli DG, Benassi MT. Antioxidant activity, polyphenols, caffeine and melanoidins in soluble coffee: the influence of processing conditions and raw material. Food Chem 2011;124:863-8.

4. Campbell TW, Bartley EE, Bechtle RM, Dayton AD. Coffee grounds. I. Effects of coffee grounds on ration digestibility and diuresis in cattle, on in vitro rumen fermentation, and on rat Growth. J Dairy Sci 1976;59:1452-60.

5. Seo J, Jung JK, Seo S. Evaluation of nutritional and economic feed values of spent coffee grounds and Artemisia princeps residues as a ruminant feed using in vitro ruminal fermentation. Peer J 2015;3:e1343.

6. Givens DI, Barber WP. In vivo evaluation of spent coffee grounds as a ruminant feed. Agric Wastes 1986;18:69-72.

7. Pond WG, Church DC, Pond KR, others. Basic animal nutrition and feeding. 4 th ed. Wiley india Pvt. Ltd., New Delhi, 
India: John Wiley and Sons; 1995.

8. de Brito CBM, Félix AP, de Jesus RM, et al. Digestibility and palatability of dog foods containing different moisture levels, and the inclusion of a mould inhibitor. Anim Feed Sci Technol 2010;159:150-5.

9. Baumont R. Palatability and feeding behaviour in ruminants. A review. Ann Zootech 1996;45:385-400.

10. Ando S, Ishida M, Oshio S, Tanaka O. Effects of isolated and commercial lactic acid bacteria on the silage quality, digestibility, voluntary intake and ruminal fluid characteristics. AsianAustralas J Anim Sci 2006;19:386-9.

11. Agarwal R, Lata S, Gupta M, Singh P. Removal of melanoidin present in distillery effluent as a major colorant: A Review. J Environ Biol 2010;31:521-8.

12. Tondee T, Sirianuntapiboon S. Decolorization of molasses wastewater by Lactobacillus plantarum No. PV71-1861. Bioresour Technol 2008;99:6258-65.

13. Sneasth PHA, Mair NS, Sharpe ME, Holt JG. Bergey's manual of systematic bacteriology, Volume 2. New York, NY: Springer US; 2005.

14. Li DH, Kim BG, Lee SR. A respiration-metabolism chamber system for measuring gas emission and nutrient digestibility in small ruminant animals. Rev Colomb Cienc Pecu 2010;23: 444-50.

15. National Research Council. Nutrient requirements of small ruminants. Washington, DC, USA: National Academy Press; 2007.

16. Latimer JW, Horwitz W. Official methods of analysis of AOAC International. 18th ed. Washington, DC, USA: AOAC International Press; 2005.

17. Soest PJV, Robertson JB, Lewis BA. Methods for dietary fiber, neutral detergent fiber, and nonstarch polysaccharides in relation to animal nutrition. J Dairy Sci 1991;74:3583-97.

18. Licitra G, Hernandez TM, Van Soest PJ. Standardization of procedures for nitrogen fractionation of ruminant feeds. Anim
Feed Sci Technol 1996;57:347-58.

19. Cai Y, Benno Y, Ogawa M, Kumai S. Effect of applying lactic acid bacteria isolated from forage crops on fermentation characteristics and aerobic deterioration of Silage. J Dairy Sci 1999; 82:520-6.

20. Chaney AL, Marbach EP. Modified reagents for determination of urea and ammonia. Clin Chem 1962;8:130-2.

21. Fussell RJ, McCalley DV. Determination of volatile fatty acids $\left(\mathrm{C}_{2}-\mathrm{C}_{5}\right)$ and lactic acid in silage by gas chromatography. Analyst 1987;112:1213-6.

22. Littell RC, Milliken GA, Stroup WW, Wolfinger RD, Schabenberger O. SAS for mixed models. Cary, NC, USA: Institute Inc; 2007.

23. Bekedam EK. Coffee brew melanoidins: structural and functional poperties of brown-colored coffee compounds. [Ph. D. thesis]. Wageningen, Netherlands: Wageningen University; 2008.

24. Givens DI, Barber WP. In vivo evaluation of spent coffee grounds as a ruminant feed. Agric Wastes 1986;18:69-72.

25. Xu CC, Cai Y, Zhang JG, Ogawa M. Fermentation quality and nutritive value of a total mixed ration silage containing coffee grounds at ten or twenty percent of dry matter. J Anim Sci 2006; 85:1024-9.

26. Axelsson L, Ahrné S. Lactic acid bacteria. Applied microbial systematics. Dordrecht, The Netherlands: Springer; 2000. pp. 367-88.

27. Seo JK, Kim SW, Kim MH, et al. Direct-fed microbials for ruminant animals. Asian-Australas J Anim Sci 2010;23:165767.

28. Maughan RJ, Griffin J. Caffeine ingestion and fluid balance: a review. J Hum Nutr Diet 2003;16:411-20.

29. Borrelli RC, Visconti A, Mennella C, Anese M, Fogliano V. Chemical characterization and antioxidant properties of coffee melanoidins. J Agric Food Chem 2002;50:6527-33. 